\title{
Aerial parts of cassava as partial replacement for feed concentrates in the diet of lambs raised in semi-confinement
}

\section{Parte aérea da mandioca em substituição parcial a alimentos concentrados na dieta de cordeiros semi-confinados}

\author{
Luiz Carlos Pereira ${ }^{1 *}$; Luís Carlos Vinhas Itavo $^{2}$; Rodrigo Gonçalves Mateus ${ }^{3}$; \\ Eduardo Souza Leal ${ }^{4}$; Urbano Gomes Pinto Abreu ${ }^{5}$; Eriklis Nogueira ${ }^{5}$; \\ Marcos Barbosa-Ferreira ${ }^{6}$; Cristiano Marcelo Espinola Carvalho ${ }^{7}$
}

\begin{abstract}
This study aimed to evaluate the performance and economic viability of including the aerial parts of cassava (PAM) in the feed of semi-confined lambs for partial reduction of food concentrates. Fifty-six sheep, including males and females of the Pantaneira genetic group weighing $18.84 \pm 2.02 \mathrm{~kg}$ on an average were used. The experiment was conducted in a factorial randomized complete block design with four treatments, each with seven females and seven males. Each group of 14 animals received one of four treatments: control, $10 \%$ of food concentrate in diet replaced with PAM, 20\% replaced with PAM, and $30 \%$ replaced with PAM. The average total gain in weight (GWT) of the male lambs was $26.89 \%$ higher than the gains observed in females. Based on the cost analysis, we observed a linear effect $(\mathrm{P}<$ $0.01)$, i.e., a decrease in the feed cost for male and female groups with increase in PAM content. For the study period, the expenditure for the control male group was the highest at $\$ 17.60$ per animal. Expenditure for the PAM 30 male group was the lowest at $\$ 12.74$ per animal. These figures reflect the actual operating costs (COE), i.e., the power is $75.78 \%$ and $74.77 \%$, for male and female groups respectively. The total cost, decreased linearly $(\mathrm{P}<0.05)$ with PAM 30 treatment costing the least at $\$$ 47.90 , which was $\$ 7.02$ lower than the control. When assessing the net margin per kilogram among the female groups, we observed a quadratic effect $(\mathrm{P}<0.01)$ with a maximum gain of $23.98 \%$ when adding PAM and $\$ 0.50 \mathrm{~kg}^{-1}$. Our results show that the raising of lambs in semi-confinement was economically viable, and the addition of the aerial part of processed cassava in the feed presented a higher economic return. Further, the addition of aerial parts of cassava did not affect the performance of the lambs.
\end{abstract}

Key words: Fodder. Nutrition. Production cost. Sheep.

\footnotetext{
${ }^{1}$ Pesquisador, Laboratório de Biotecnologia Aplicada a Nutrição Animal, Universidade Católica Dom Bosco, UCDB, Campo Grande, MS, Brasil. Funded project FUNDECT, and CAPES Foundation Manoel of Barros. E-mail: luizcp.agro@gmail.com

2 Prof., Programa de Pós-graduação em Ciência Animal, Universidade Federal Mato Grosso do Sul, UFMS, Campo Grande, MS, Brasil. E-mail: luis.itavo@ufms.br

3 Prof., Programa de Pós-graduação em Ciências Ambientais e Sustentabilidade Agropecuária, UCDB, Campo Grande, MS, Brasil. E-mail: rf4789@ucdb.br

${ }^{4}$ Discente de Doutorado, Programa de Pós-graduação em Ciências Ambientais e Sustentabilidade Agropecuária, UCDB, Campo Grande, MS, Brasil. E mail: eduardoleal.zoo@gmail.com

${ }^{5}$ Pesquisadores, Embrapa Pantanal, EMBRAPA, Corumbá, MS, Brasil. E mail: urbano.abreu@embrapa.br; eriklis.nogueira@ embrapa.br

${ }^{6}$ Prof., Programa de Pós-graduação Mestrado em Produção e Gestão Agroindustrial, Universidade Anhanguera, UNIDERP, Campo Grande, MS, Brasil. E-mail: marcos.barbosa@uniderp.edu.br

7 Prof. e Coordenador, Programa de Pós-graduação Doutorado em Biotecnologia, UCDB, Campo Grande, MS, Brasil. E-mail: cristiano@ucdb.br

* Author for correspondence
} 


\title{
Resumo
}

\begin{abstract}
Objetivou-se avaliar o desempenho produtivo e viabilidade econômica da inclusão da parte aérea de mandioca in natura na ração de cordeiros semi-confinados, em busca da redução parcial de alimentos concentrados. Foram utilizados 56 ovinos da raça Pantaneira, sendo 28 machos e 28 fêmeas, com idade média de 75 dias, pesos médios de $18,84 \mathrm{~kg} \pm 2,02$, avaliados durante os meses de janeiro a março de 2015, totalizando 65 dias. O delineamento experimental foi em blocos inteiramente casualizados com quatro tratamentos, cada um com 7 fêmeas e 7 machos, sendo que foram divididos de forma que os pesos e os animais fossem o mais homogêneos. Cada grupo de 14 animais recebeu um dos quatro tratamentos: Controle; tratamento com adição de 10\% PAM em substituição ao concentrado; tratamento com adição de $20 \%$ de PAM em substituição ao concentrado e tratamento com adição de $30 \%$ de PAM em substituição ao concentrado. O valor de ganho médio total (GPT) dos cordeiros machos foi $26,89 \%$ superior aos ganhos observados no grupamento de fêmeas. Com base no centro de custos foi observado efeito linear $(\mathrm{P}<0,01)$ decrescente no valor da alimentação para os grupamentos de macho e fêmea. Sendo o tratamento controle o maior dispêndio no período com $\mathrm{R} \$ 56,86$ animal $^{-1}$ e o tratamento PAM 30 o menor valor com $\mathrm{R} \$ 41,17$ animal $^{-1}$ no grupamento de machos. Estes valores refletiram no custo operacional efetivo (COE), ou seja, a alimentação representa 75,78\% e 74,77\%, do COE para os grupamentos de macho e fêmea respectivamente. $\mathrm{O}$ custo total apresentou efeito linear $(\mathrm{P}<0,05)$ decrescente, o tratamento PAM 30 o menor valor apurado R $\$ 154,72$. Resultando em redução no custo total em $\mathrm{R} \$ 22,69$ em relação ao tratamento controle ( $\mathrm{R} \$ 177,41)$. Ao se avaliar a margem liquida por quilo dentre o grupamento de fêmeas observou efeito quadrático $(\mathrm{P}<0,01)$ com ponto de máxima em $23,98 \%$ de adição de PAM e valor em $\mathrm{R} \$ 1,61 \mathrm{Kg}$ ganho-1. Conclui-se a terminação de cordeiros em semi-confinamento, foi economicamente viável, tendo apresentado maior retorno econômico com a adição da parte aérea de mandioca in natura na ração, não afetando o desempenho dos cordeiros.
\end{abstract}

Palavras-chave: Forragem; custo de produção; nutrição; ovinos.

\section{Introduction}

In Brazil, the number of sheep recorded in 2014 was 17.61 million heads. The Mato Grosso do Sul State has approximately 502,678 heads, an increase by $20.44 \%$ in the last 10 years (IBGE, 2015). There has been a recovery in the demand for lamb in both the domestic and foreign markets, which has ensured good profitability. However, to ensure growth, the production sector needs to be better organized to adequately meet the demand (SORIO, 2011).

In this context, reducing the costs related to ruminant production has aroused interest especially in studies exploring alternative food sources to replace traditional concentrated feed, thus, providing greater competitiveness and sustainability to the sector (HOLZER et al., 1997).

A strategic and interesting alternative for sheep raised in the Cerrado weather conditions would be the use of the aerial parts of cassava (PAM), in view of its potential to generate income for farmers in the Midwest region where 87,997 hectare has been planted with cassava (IBGE, 2015). PAM can be supplied either raw or as hay or silage, making it possible to use it as an alternative to be included in feed formulation for ruminants (MODESTO et al., 2004; FERNANDES et al., 2011; SOUZA et al., 2012).

Different cassava cultivars used for forage production showed average yields of $12.1 \mathrm{t} \mathrm{ha}^{-1}$ of green matter (CARVALHO et al., 1985). Forage derived from cassava are high in protein content, which varies throughout the year from 20 to $38.4 \%$ (MODESTO et al., 2004), and low in fiber content, when compared to other fodder crops such as Brachiaria (CARVALHO et al., 1983; MODESTO et al., 2004; MELO et al., 2008).

In addition, cassava is cyanogenic and has toxic compounds that vary in concentration in the different cultivars (BUTOLO, 2002; OTSUBO, 2004). Hydrocyanic acid (HCN) is extremely toxic 
to any animal when ingested, and concentrations greater than $2.4 \mathrm{mg} \mathrm{g}^{-1} \mathrm{HCN} \mathrm{kg}^{-1}$ live weight can cause acute poisoning leading to death (SOARES, 1989).

Phengvichith and Ledin (2007) reported that fresh cassava leaves contains $325 \mathrm{mg} \mathrm{kg}^{-1}$ $\mathrm{HCN}$. After $1 \mathrm{~h}$ of drying in the shade, the $\mathrm{HCN}$ level decreased to $145 \mathrm{mg} \mathrm{kg}^{-1}$. Sun drying can eliminate almost $90 \%$ of the initial $\mathrm{HCN}$ content (RAVINDRAN et al., 1987; RAVINDRAN, 1993; WANAPAT et al., 1997). Animals that continuously consume cassava show increased serum levels of the enzyme rhodanase, which is responsible for the detoxification of cyanide, conferring tolerance to $\mathrm{HCN}$ levels that would otherwise be toxic (TOKARNIA et al., 2000).

Improvement of animal nutrition quality associated with low production cost and resultant increased production efficiency is necessary for sustaining human life in in rural areas. The present study aimed at evaluating the performance and economic viability of including PAM in the diet of semi-confined lambs for partial reduction of concentrated feed.

\section{Materials and Methods}

The experiment was conducted at the Sheep Technology Center (CTO) at the Farm School Três Barras, Manoel de Barros Foundation located in the city of Campo Grande, Mato Grosso do Sul (29 $33^{\prime} 51.96^{\prime \prime} \mathrm{S}$ and $\left.54^{\circ} 32^{\prime} 29.09^{\prime \prime} \mathrm{W}\right)$. This research was approved by the Anhanguera Educacional Ltda Committee of Ethics for the Use of Animals (CEUA/EASA), Permit No. 2062.

We used 56 sheep (28 males and 28 females) of the Pantaneiro genetic group, that were, on an average, 75 days old at the beginning of the study. The average weight was $18.84 \pm 2.02 \mathrm{~kg}$. The study was conducted between January and March 2015, for a total of 65 days. The animals were kept in a 2.6 ha pasture where Panicum maximum Massai was cultivated. The pasture was divided into four paddocks of equal area, and the animals were supplied with water ad libitum and feed twice a day (08h30 and 16h00). To avoid any possible effects because of differences in availability and nutritional value of grazing between the paddocks, we ensured that each treatment group was not always grazed in the same paddock, but were rotated among paddocks every seven days. Before each rotation, the animals were weighed.

All animals were weighed at the beginning of the study, identified, and treated against worms homogenizing the groups. During the experimental period, the animals were weighed fasted solid food during 8 hours every seven (7) days. A randomized block design was used for the factorial experiment with four treatments, each with 7 females and 7 males. The diets used in this study were control (CT), which was a concentrated feed based on corn and soybean meal with minerals; treatment replacing $10 \%$ of the concentrated feed with PAM (PAM 10); treatment replacing $20 \%$ of the concentrated feed with PAM (PAM 20); and treatment replacing 30\% of the concentrated feed with PAM (PAM 30).

PAM, made up of leaves, stems, and branches, was minced and homogenized in a stationary chopper, left for $12 \mathrm{~h}$ in the shade, and later provided as feed. To prevent risk of cyanide poisoning, the experiment was carried out after the animals were allowed to adapt for 7 days. The cassava variety IAC 576 was used, which was planted on 3 and May 18, 2014. For the purpose of this experiment, we used $1 \mathrm{~m}$ spacing between rows, and $0.40,0.60$, and 0.80 $\mathrm{m}$ spacing between plants in a row, giving a total of 25,000; 16,700; and 12,500 plants ha $^{-1}$, respectively. The experimental plot consisted of six rows of plants, each $20 \mathrm{~m}$ long, covering a plot area of $120 \mathrm{~m}^{2}$. Each of the spacing between the plants was represented by four replications, totaling twelve such plots. As per the recommended fertilization for cassava crop (RAIJ et al., 1997), nitrogen, phosphorus, and potassium (NPK 8:20:20) fertilizer was used with nitrogen (ammonium sulfate) topdressing at 60 days 
after seedling emergence. PAM was harvested at 185 days after emergence (DAE), cutting it to 20 $\mathrm{cm}$ from the ground.

PAM, concentrated feed, and weekly samples of pasture collected were analyzed for chemical composition and digestibility. After harvesting, the biomass was made into composite samples by date, type, and experimental group. Each sample was packed in a paper bag, labeled, and dried in an oven by forced air circulation at $55{ }^{\circ} \mathrm{C}$ for $72 \mathrm{~h}$. These were subsequently ground in a mill and sieved using a 1-mm-diameter sieve. The samples were then sent to the Applied Biotechnology Laboratory of Animal Nutrition at the Dom Bosco Catholic University (UCDB) for analysis. The dry matter (DM), organic matter (OM), and crude protein (CP) contents were determined according to the methods described by Silva and Queiroz (2006) and neutral detergent fiber (NDF) and acid detergent fiber (ADF) contents were determined according to the methods described by Van Soest (1965). For determination of the digestibility in vitro (DIV), we adopted the technique described by Tilley and Terry (1963) and adapted it for the artificial rumen developed by ANKOM ${ }^{\circledR}$ as described by Holden (1999), by using the methodology of ruminal fermenter (anaerobic incubator, MA443 model, Marconi).

After harvesting PAM samples were packed with ice in an insulated box and sent to the Cross Pond Farm Laboratory of UCDB, Campo Grande, Mato Grosso do Sul, where each fraction was separated and identified. The residual $\mathrm{HCN}$ were determined using the alkaline picrate method (BRITO et al., 2013), and the result was expressed in mg equivalent of $\mathrm{HCN} \mathrm{g}^{-1}$ dry matter.

The diet of the control group was formulated to meet the nutritional requirements of lambs such that they gain an average daily weight of $0.20 \mathrm{~kg}$ (NRC, 2007). The control diet comprised $60 \%$ concentrate and $40 \%$ roughage pasture. The nutritional value of the feed was estimated at $18 \% \mathrm{CP}$ and $70 \%$ total digestible nutrients (TDN), as shown in Table 1.

Table 1. Bromatological analysis of the shoot of cassava (Manihot esculenta Crantz), Panicum maximum 'Massai', and concentrated commercial sheep feed. The partial in-vitro digestibility and cyanide levels from the shoot of cassava are shown.

\begin{tabular}{lccc}
\hline Variables & PAM & $\begin{array}{c}\text { Panicum maximum } \\
\text { 'Massai' }\end{array}$ & concentrated \\
\hline Dry matter & 29.21 & 31.04 & 84.37 \\
Organic matter & 92.22 & 89.85 & 86.45 \\
Crude protein & 14.10 & 12.74 & 21.00 \\
Neutral detergent fiber & 58.63 & 74.70 & 17.92 \\
Acid detergent fiber & 40.25 & 42.45 & 11.08 \\
In-vitro digestibility of dry matter & 62.27 & 58.64 & - \\
In-vitro digestibility of organic matter & 95.27 & 89.71 & - \\
Cyanide (mg g & ) & - & - \\
\hline
\end{tabular}

The shoot of the cassava (PAM); Panicum maximum 'Massai' (Massai). The centesimal composition of concentrated feed was 1.35\% Calcium, 0.5\% Phosphorus, 0.5\% Magnesium, 0.05\% Sulfur, 0.1065\% Sodium, 0.7\% Cobalt, 0.3\% Selenium, 0.081\% Iodine, 0.4\% Zinc, 1.8\% Manganese, 5.46\% Copper, 3\% Ether extract, 2.4\% Mineral matters, and 7\% Bacillus subtilis $1.3500 \times$ 10 E8 UFC kg, Bifidobacterium bifidum $4.5000 \times 10$ E7 UFC kg, Enterococcus faecium $4.5000 \times 10$ E7 UFC kg, Lactobacillus acidophilus $4.5000 \times 10 \mathrm{E} 7 \mathrm{UFC} \mathrm{kg}{ }^{-1}$, Lactobacillus buchneri $9.0000 \times 10 \mathrm{E} 7 \mathrm{UFC} \mathrm{kg}$; Lactobacillus casei $4.5000 \times 10 \mathrm{E} 7 \mathrm{UFC}$ $\mathrm{kg}$, Saccharomyces cerevisiae $3.0000 \times 10$ E7 UFC kg

Commercial concentrate for sheep, Adames Animal nutrition. 
The following performance and productivity indices were calculated: total consumption (CT) and daily consumption (CD) with PAM supplement and concentrate, average daily weight gain (GWD), average total weight gain (GWT), and feed conversion index (ICA). For comparison, historical data of animal performance for average age at weaning (in days), birth weight (in $\mathrm{kg}$ ), and average weight at weaning (in $\mathrm{kg}$ ) were used (Table 2).

Table 2. Pantaneiros sheep performance from birth to weaning.

\begin{tabular}{lcc}
\hline Variables & Males & Females \\
\hline Median age when weaned (days) & 79 & 78 \\
Birth weight $(\mathrm{kg})$ & 3.83 & 3.66 \\
Average weight at weaning $(\mathrm{kg})$ & 16.66 & 14.48 \\
\hline
\end{tabular}

To calculate production costs we used the effective operating cost (COE), total operating cost (TOC), and total cost (TC), following Hoffmann et al. (1987). The above cost classifications allowed the identification of income and profitability indicators, which were the basis for the analysis of production systems, according to the methodology defined by Martin et al. (1998). Production system analysis was done using the total revenue (RT), which included all cash inflows from the sale of cassava root in different production systems. We determined the point of breaking-even by using the equation $\mathrm{Q}=\mathrm{CT} / \mathrm{P}$, where $\mathrm{Q}$ is the live weight (in $\mathrm{kg}$ ) produced against the total amount invested during the experimental period, CT is the total cost, and $\mathrm{P}$ is the market price of the product $\left(\$ \mathrm{~kg}^{-1}\right)$. The cost of PAM was determined from Table 3.

Table 3. Cutting costs and providing PAM for sheep per ha' ${ }^{-1}$.

\begin{tabular}{lcccr}
\hline Indicators & Un. & Quant. & Unit price (\$) & Total (\$) \\
\hline PAM cutting & Man hours & 45 & 4.15 & 186.82 \\
PAM transport & ton $\mathrm{km}^{-1}$ & 24.10 & 3.69 & 163.13 \\
Electric energy & $\mathrm{kWh}$ & 90 & 0.11 & 10.58 \\
Food Supply in the trough & time & 45 & 4.15 & 186.82 \\
Maintenance of equipment & & & 6.19 & 6.19 \\
Cost of PAM $\left(\$ \mathrm{ha}^{-1}\right)$ & & & $\mathbf{5 5 3 . 5 7}$ \\
Cost of PAM $(\$ \mathrm{~kg})$ & & & & $\mathbf{0 . 0 2}$ \\
\hline
\end{tabular}

Costs were determined based on the cost of planting cassava and the methodology and considerations used in the experiment. Un.: Units; Quant.: Quantity. Total cost of PAM $\left(\$ \mathrm{ha}^{-1}\right)$ divided by the estimated total green biomass production per hectare of PAM (29.8 ton).

The data were subjected to analysis of variance (ANOVA, $\mathrm{P}<0.05$ ), linear regression, and Pearson correlation, following Levine (2000), by using the SAS statistical software version 9.1 (2004).

\section{Results and Discussion}

Performance of the animals was not correlated $(\mathrm{P}>0.05)$ with the treatments. However when comparing genders, our analysis showed significant difference $(\mathrm{P}<0.05)$ for final weight $(\mathrm{FW}), \mathrm{GWT}$, and GWD. The average FWs of the control group, PAM 10, PAM 20, and PAM 30 for males were $31.47,29.94,29.24$, and $28.1 \mathrm{~kg}$, respectively, which were higher than the average weights of the respective female groups: $26.75,25.41,26.72$, and $27.38 \mathrm{~kg}$ (Table 4). 
The average GWT in male lambs was $26.89 \%$ higher than that in females. It may be noted that the PAM 10 treatment resulted in a higher average GWT $(11.64 \mathrm{~kg})$ in males, while in females it resulted in a lower average GWT (6.86 kg).
The average GWD in this study was higher than that in other studies on lambs between 60 and 100 $\mathrm{g}$ day $^{-1}$ (OLIVEIRA et al., 2013; MANERA et al., 2014). The larger weight gain by males is expected as their physiology promotes higher growth rate (WYLIE et al., 1997).

Table 4. Performance of semi-confined sheep after 65 days of feeding concentrated feed partially substituted with the aerial parts of cassava.

\begin{tabular}{lllllllll}
\hline Indexes & Control & PAM 10 & PAM 20 & PAM 30 & Equation & R2 & $P$ \\
\hline & \multicolumn{7}{c}{ Male } \\
\hline Initial weight (kg) & 19.95 & 18.30 & 18.99 & 18.63 & $y=$ & 18.96 & 0.62 & 0.471 \\
Final Weight (kg) & 31.47 & 29.94 & 29.24 & 28.10 & $y=$ & 29.68 & 0.98 & 0.155 \\
GWT (kg) & 11.51 & 11.64 & 10.24 & 9.46 & $y=$ & 10.71 & 0.86 & 0.248 \\
GWD (g) & 177 & 179 & 157 & 133 & $y=$ & 161.50 & 0.86 & 0.588 \\
\hline \multicolumn{7}{c}{ Female } \\
\hline Initial weight (kg) & 18.92 & 18.55 & 17.99 & 19.41 & $y=$ & 18.71 & 0.78 & 0.443 \\
Final Weight (kg) & 26.75 & 25.41 & 26.72 & 27.38 & $y=$ & 26.57 & 0.73 & 0.427 \\
GWT (kg) & 7.83 & 6.86 & 8.73 & 7.91 & $y=$ & 7.83 & 0.13 & 0.789 \\
GWD (g) & 120 & 105 & 134 & 121 & $y=$ & 120 & 0.12 & 0.786 \\
\hline
\end{tabular}

Total weight gain averaged across all animals in a group (GWT); Average daily weight gain (GWD) in grams; P- effect (P< 0.05).

Total consumption of PAM showed a positive linear effect $(\mathrm{P}<0.01)$, with maximum consumption of $13.26 \mathrm{~kg}$ by females and $13.18 \mathrm{~kg}$ by males in the PAM 30 treatment. The dry matter intake of PAM was almost the same: $58 \mathrm{~g}$ per animal in the PAM 30 treatment. As the percentage of PAM addition increased in the diet, the consumption of concentrated feed decreased linearly. Thus, the highest consumption of concentrated feed was observed for animals in the control group, with 643 g per animal, and the lowest was for the PAM 30 group at $407 \mathrm{~g}$ per animal (Table 5).

The consumption of total dry matter is of fundamental importance, since the ration provided influences the performance of lambs (ARAÚJO et al., 2014). Thus, the observed linear effect for total consumption of dry matter with the addition of PAM resulted in low food consumption, as the supply of feed was 649 and $609 \mathrm{~g}$ per animal in the male PAM 20 and PAM 30 treatment groups. This was similar to the total consumption values for dry matter reported by Souza et al. (2010). However, we noted that the female group showed a negative quadratic effect, having minimum point with the addition of $26.23 \%$ of PAM, and the total dry matter intake was $613 \mathrm{~g}$ per animal.

In males, a quadratic relationship $(\mathrm{P}<0.01)$ was noted between PAM levels in the feed and CP intake, which decreased with the addition of PAM, with a minimum $\mathrm{CP}$ intake of $159.8 \mathrm{~g}$ per animal in diet with the addition of $26.41 \%$ PAM (Table $5)$. The decrease in dry matter consumption, and consequently the CP intake, was because of the moisture content of PAM compared to concentrated feed, corroborating the results of other studies that evaluated the use of PAM in feed (URBANO et al., 2015). 
Table 5. Nutrient consumption of semi-confined sheep that were fed concentrated feed with different levels of cassava aerial parts for 65 days.

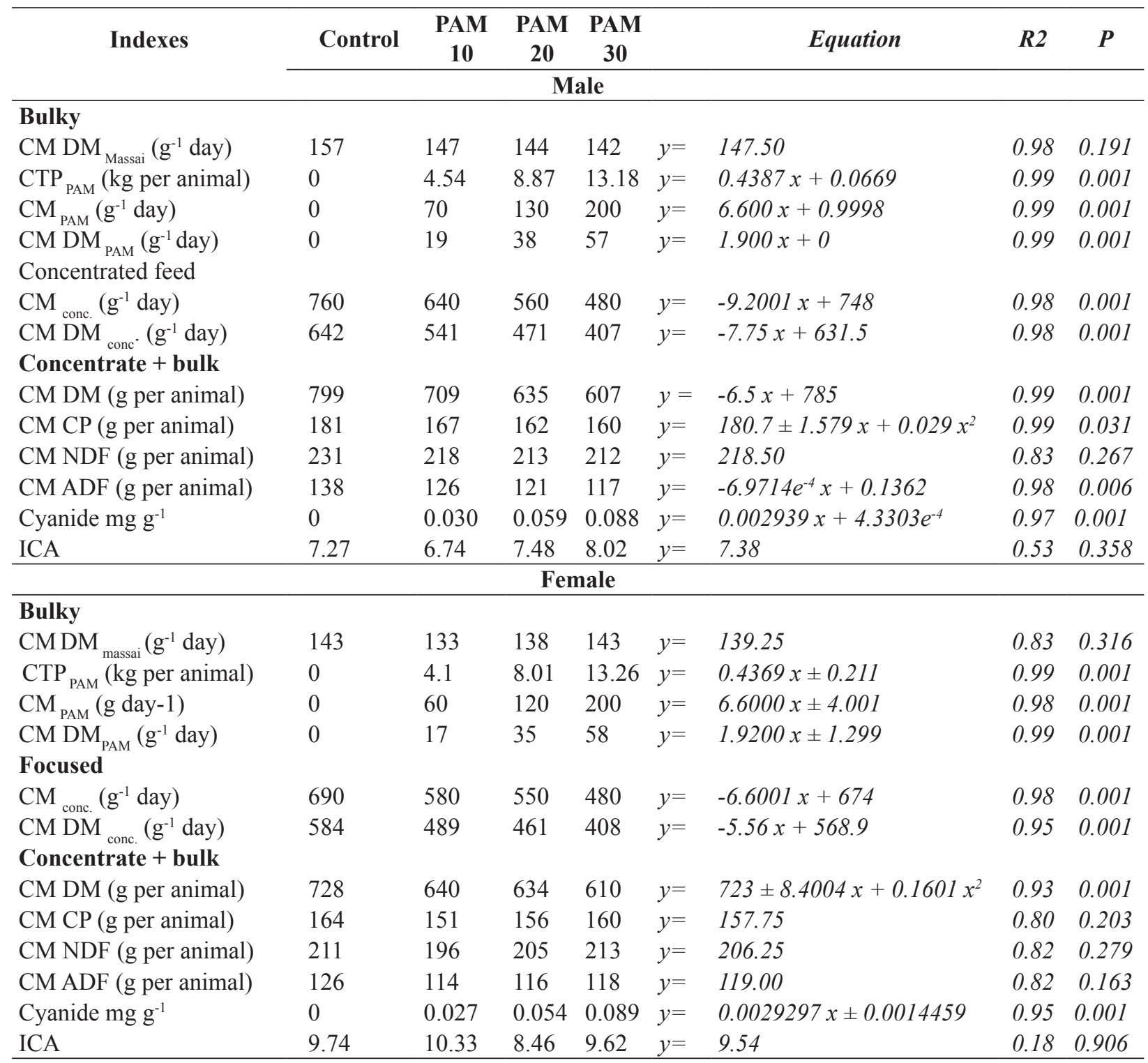

Total consumption of PAM in the experimental period (CTP $\left.{ }_{\text {PAM }}\right)$; average consumption of concentrated feed (CM $\left.{ }_{\text {conc }}\right)$; average consumption of PAM ( $\left.\mathrm{CM}_{\text {PAM }}\right)$; average consumption of milk dry matter in the concentrated feed (CM DM conc.); average consumption of crude protein in concentrate feed $\left(\mathrm{CM} \mathrm{CP}{ }_{\text {conc }}\right)$; average consumption of PAM dry matter $\left(\mathrm{CM} \mathrm{DM}_{\mathrm{PAM}}\right)$; estimated average dry matter consumption of Panicum maximum 'Massai' (CM DM ${ }_{\text {massai }}$ ); average consumption of dry matter (DM), average consumption of crude protein (CP), average fiber consumption of in neutral detergent (CM NDF); average fiber consumption of acid detergent (CM ADF); feed conversion index (ICA). P- effect significant at the 0.05 level.

NDF in the diet did not change with the addition of PAM, although there were differences in the total dry matter consumption, which was evaluated separately (Table 5).

The similar productive performance among male lambs is related to the linear decrease in the average consumption of $\mathrm{ADF}$, which allowed adequate fermentation to potentially digest the ADF with the addition of PAM in the ration, favoring increased supply of nitrogen release for microbial protein synthesis (VAN SOEST, 1994; DETMANN et al., 2014). Further, supplementation with grains 
increases productivity levels when good quality roughage is provided in the diet (SOARES et al., 2013).

For males, the best ICA, i.e., the treatment for which feed was most efficiently converted to weight gain, was noted for the PAM 10 treatment at $6.74 \%$ compared to $7.86 \%, 10.98 \%$, and $18.99 \%$ for the control, PAM 20, and PAM 30 treatments, respectively. For females, the best ICA was noted for the PAM 20 treatment at $8.46 \%$ and the lowest ICA was for the PAM 10 treatment at $10.33 \%$ (Table $5)$.

Cyanide consumption increased significantly $(\mathrm{P}<0.01)$ with increase in PAM level in the diet (Table 5). Although a higher level of cyanide was consumed with the addition of $30 \%$ PAM $(0.188 \mathrm{mg}$ $\mathrm{kg}^{-1}$ body weight), this was below the toxic levels described by Soares (1989).

In the course of the experiment, it was observed that the lambs showed a preferential consumption behavior for PAM. This can be attributed to palatability, the animal's sensory perception of food, which includes odor, texture, and sensation when chewing (HILL, 2007; CARCIOFI, 2008), and to the nutritional quality of roughage, which determines performance.

Because Sheep, are selective in their feed (FIALHO; VIEIRA, 2011), the palatability of PAM can be defined by the integrated responses of taste and internal signals of the central nervous system because of previous food associations (FORBES, 1998). According to Goularte et al. (2011), the concentrated feed pellets or powdered reduce rumination, while the forage tends to increase rumination time per gram of food. Thus, PAM increased the effectiveness of masticatory activity of sheep, resulting in increased buffering capacity (OWENS and GOETSCH, 1988; VAN SOEST, 1994), which in turn contributed to improved rumination
Our analyses revealed that the FW is positively correlated with the initial weight (SW), total diet consumption (CTD), average dry matter intake (DMI), total crude protein consumption (CCP), total neutral detergent fiber consumption (CNDF), and total acid detergent fiber consumption (CADF). However, the DMI was negatively correlated with cyanide levels (Table 6).

The negative correlation between DMI and cyanide can be explained by the lower intake of dry matter in the treatments with increased PAM intake.

The positive correlations between the factors are associated with performance and rate of consumption, the lambs that initiated the heavier experiment had higher body weight (Table 6). According to Vaz et al. (2011), performance (weight and production level) of ruminants is governed by the consumption of food, especially, qualitative factors such as fiber content and energy.

We observed a significant linear relationship $(\mathrm{P}<0.01)$ where increase of PAM in the diet decreased the production cost for both males and females (Table 7). The control treatment showed the highest expenditure, with $\$ 17.60$ per animal for males, and the PAM 30 treatment showed the lowest expenditure at \$ 12.74 per animal. The effective operating cost in relation to gender was $75.78 \%$ for males and $74.77 \%$ for females.

On assessing the total cost of the semiconfinement, we noted that, for males, it decreased linearly $(\mathrm{P}<0.05)$, with the addition of PAM in the feed and was the lowest at $\$ 47.90$ for the PAM 30 treatment. The total cost reduced by $\$ 7.02$ when compared to the control group (Table 8). 
Table 6. The Pearson correlation between factors used to assess performance. This includes weight at the beginning of the study (SW), final average weight in $\mathrm{kg}(\mathrm{FW})$, total consumption of diet (CTD), total dry matter intake (DMI), total consumption of crude protein (CCP), total consumption of neutral detergent fiber (CNDF), and total consumption of acid detergent fiber (CADF).

\begin{tabular}{lllllllll}
\hline & SW & FW & CTD & DMI & CCP & CNDF & CADF & CYANIDE \\
\hline SW & 1 & $0.559 * *$ & $0.799 * *$ & $0.652 * *$ & $0.769 * *$ & $0.804 * *$ & $0.757 * *$ & 0.063 \\
& & 0.001 & 0.001 & 0.001 & 0.001 & 0.001 & 0.001 & 0.643 \\
FW & $0.559 * *$ & 1 & $0.867 * *$ & $0.740 * *$ & $0.846 * *$ & $0.866 * *$ & $0.836 * *$ & -0.004 \\
& 0.001 & & 0.001 & 0.001 & 0.001 & 0.001 & 0.001 & 0.977 \\
CTD & $0.799 * *$ & $0.867 * *$ & 1 & $0.866 * *$ & $0.981 * *$ & $0.999 * *$ & $0.971 * *$ & -0.028 \\
& 0.001 & 0.001 & & 0.001 & 0.001 & 0.001 & 0.001 & 0.836 \\
DMI & $0.652 * *$ & $0.740 * *$ & $0.866 * *$ & 1 & $0.947 * *$ & $0.843 * *$ & $0.961 * *$ & $-0.524 * *$ \\
& 0.001 & 0.001 & 0.001 & & 0.001 & 0.001 & 0.001 & 0.001 \\
CCP & $0.769 * *$ & $0.846 * *$ & $0.981 * *$ & $0.947 * *$ & 1 & $0.971 * *$ & $0.999 * *$ & -0.222 \\
& 0.001 & 0.001 & 0.001 & 0.001 & & 0.001 & 0.001 & 0.100 \\
CNDF & $0.804 * *$ & $0.866 * *$ & $0.999 * *$ & $0.843 * *$ & $0.971 * *$ & 1 & $0.959 * *$ & 0.017 \\
& 0.001 & 0.001 & 0.001 & 0.001 & 0.001 & & 0.001 & 0.902 \\
CADF & $0.757 * *$ & $0.836 * *$ & $0.971 * *$ & $0.961 * *$ & $0.999 * *$ & $0.959 * *$ & 1 & $-0.267 *$ \\
& 0.001 & 0.001 & 0.001 & 0.001 & 0.001 & 0.001 & & 0.046 \\
CYANIDE & 0.063 & -0.004 & -0.028 & $-0.524 * *$ & -0.222 & 0.017 & $-0.267 *$ & 1 \\
& 0.643 & 0.977 & 0.836 & 0.001 & 0.100 & 0.902 & 0.046 & \\
\hline
\end{tabular}

**The correlation is significant at the 0.01 level; *The correlation is significant at the 0.05 level. All values from the four experimental groups have been used.

Considering that the different diet treatments resulted in an even performance, we did not record a relationship between the total revenue and the level of PAM in the diet. However, between the sexes there was considerable difference. Male groups recorded a mean gross revenue gain of $\$ 5.84$ higher than that by the female groups (Table 8 ). This is attributed to the greater FW of the animals, which translates to higher gross income, confirming the observations of Paim et al. (2011).

Among the female groups, the economic return per animal was observed to increase linearly
( $\mathrm{P}<0.05)$ with increasing substitution of PAM in the food. These results are associated with different performances of the animals and price of the supplied feed (CARVALHO et al., 2015). The treatment without addition of PAM had the lowest amount of 0.31 per animal and replacing 30\% of PAM in the diet had the highest economic return (\$ 4.14 per animal). This value was lower than that for the male control group ( $\$ 6.45$ per animal), PAM 10 (\$ 8.46 per animal), PAM 20 (\$ 7.49 per animal), and PAM 30 (\$ 6.91 per animal). 
Table 7. Costs involved in the raising of sheep for 65 days in semi-confinement on diets in which the concentrated feed was replaced with different levels of the aerial parts of cassava.

\begin{tabular}{|c|c|c|c|c|c|c|c|c|}
\hline Indicators & Control & $\begin{array}{c}\text { PAM } \\
10\end{array}$ & $\begin{array}{c}\text { PAM } \\
20\end{array}$ & $\begin{array}{c}\text { PAM } \\
\text { 30 }\end{array}$ & & Equation & $R 2$ & $P$ \\
\hline \multicolumn{9}{|c|}{ Male } \\
\hline Price of the concentrate $(\mathrm{kg} \mathrm{\$ )}$ & 0,29 & 0,29 & 0,29 & 0,29 & & & & \\
\hline PAM price $(\mathrm{kg} \$)$ & 0,02 & 0,02 & 0,02 & 0,02 & & & & \\
\hline Price of $1 \mathrm{~kg} \mathrm{Lamb}(\mathrm{R} \$)$ & 1,95 & 1,95 & 1,95 & 1,95 & & & & \\
\hline Labor $(\$)$ & 1,62 & 1,62 & 1,62 & 1,62 & & & & \\
\hline Power Supply (\$) & 17,60 & 15,27 & 13,81 & 12,75 & $y=$ & $-0,1603 x+17,261$ & 0.96 & 0.001 \\
\hline Sanitation $(\$)$ & 1,42 & 1,42 & 1,42 & 1,42 & & & & \\
\hline Other Costs $(\$)$ & 1,71 & 1,71 & 1,71 & 1,71 & & & & \\
\hline Depreciation (\$) & 0,65 & 0,65 & 0,65 & 0,65 & & & & \\
\hline Investment & 31,14 & 28,55 & 29,64 & 29,07 & $y=$ & 95.62 & 0.61 & 0.472 \\
\hline Interest on Capital (\$) & 0,45 & 0,41 & 0,43 & 0,42 & $y=$ & 1.39 & 0.62 & 0.471 \\
\hline Interest on Working Capital (\$) & 0,32 & 0,29 & 0,27 & 0,25 & $y=$ & $-0,0023 x+0,318$ & 0.97 & 0.001 \\
\hline \multicolumn{9}{|l|}{ 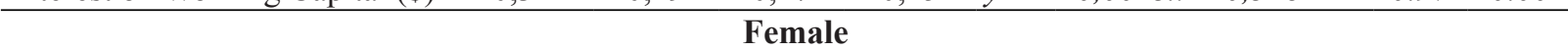 } \\
\hline Price of the concentrate $(\$ \mathrm{~kg})$ & 0,29 & 0,29 & 0,29 & 0,29 & & & & \\
\hline PAM price $(\mathrm{kg} \$)$ & 0,02 & 0,02 & 0,02 & 0,02 & & & & \\
\hline Price of kg Lamb (\$) & 1,95 & 1,95 & 1,95 & 1,95 & & & & \\
\hline Labor $(\$)$ & 1,62 & 1,62 & 1,62 & 1,62 & & & & \\
\hline Power Supply (\$) & 16,21 & 13,98 & 13,39 & 12,78 & $y=$ & $=-0,1088 x+15,723$ & 0.88 & 0.001 \\
\hline Sanitation $(\$)$ & 1,42 & 1,42 & 1,42 & 1,42 & & & & \\
\hline Other Costs $(\$)$ & 1,71 & 1,71 & 1,71 & 1,71 & & & & \\
\hline Depreciation (\$) & 0,65 & 0,65 & 0,65 & 0,65 & & & & \\
\hline Investment & 29,53 & 28,94 & 28,29 & 30,38 & $y=$ & 94.60 & 0.83 & 0.517 \\
\hline Interest on Capital (\$) & 0,43 & 0,42 & 0,41 & 0,44 & $y=$ & 1.37 & 0.84 & 0.519 \\
\hline Interest on Working Capital (\$) & 0,30 & 0,27 & 0,26 & 0,25 & $y=$ & $-0,0015 x+0,2957$ & 0.85 & 0.001 \\
\hline
\end{tabular}

P- effect significant at the 0.05 level.

For the production costs and revenue to break even for male sheep, a decreasing linear equation revealed that when PAM is added to the food, a less outlay is needed. However, lower weights were observed for the PAM 30 treatment $(24.91 \mathrm{~kg})$. This result corresponds to the $2.48 \mathrm{~kg}$ body weight gain that translates to a cost of production of $\$ 4.82$ more for the control than for the PAM 30 treatment.
Further, even with the lowest supply of crude protein day ${ }^{-1}$ (Table 5), the PAM-treated male groups did not show lower profitability than the control group, which was provided higher dry matter during the study period (Table 5). However among the group of females were observed positive quadratic equations to profitability and profitability, with maximum point at 10.09 and $11.68 \%$ respectively, obtained in the PAM 20 group (Table 8). 
Table 8. Indicators of economic viability of raising sheep for 65 days in semi-confinement on a diet where the feed concentrate has been replaced with different levels of the aerial parts of cassava.

\begin{tabular}{|c|c|c|c|c|c|c|c|}
\hline Indicators & Control & $\begin{array}{c}\text { PAM } \\
10\end{array}$ & $\begin{array}{c}\text { PAM } \\
20\end{array}$ & $\begin{array}{c}\text { PAM } \\
30\end{array}$ & Equation & $R 2$ & $\boldsymbol{P}$ \\
\hline \multicolumn{8}{|c|}{ Male } \\
\hline Effective Operating Cost (\$) & 22.36 & 20.01 & 18.56 & 17.50 & $y=-0.1603 x+22.011$ & 0.99 & 0.001 \\
\hline Total Operating Cost (\$) & 23.80 & 21.37 & 19.91 & 18.83 & $y=-0.1637 x+23,433$ & 0.97 & 0.001 \\
\hline Total Cost $(\$)$ & 54.93 & 49.93 & 49.56 & 47.90 & $y=-0.2145 x+53.796$ & 0.84 & 0.024 \\
\hline Operating Income (\$) & 22.46 & 22.71 & 19.98 & 18.46 & $y=67.51$ & 0.87 & 0.248 \\
\hline Total Revenue (\$) & 61.38 & 58.40 & 57.04 & 54.81 & $y=187.04$ & 0.98 & 0.155 \\
\hline Gross Margin (\$) & 38.93 & 35.69 & 37.05 & 36.34 & $y=119.52$ & 0.35 & 0.471 \\
\hline Net Margin (\$) & 37.60 & 37.02 & 37.12 & 35.98 & $y=119.28$ & 0.81 & 0.847 \\
\hline Economic Return (\$) & 6.46 & 8.47 & 7.48 & 6.91 & $y=23.66$ & 0.03 & 0.754 \\
\hline Break-even point $(\mathrm{kg})$ & 28.16 & 25.61 & 25,40 & 24,55 & $y=-0,11039 x+27,586$ & 0.93 & 0.024 \\
\hline Leveling price (\$) & 1.75 & 1.68 & 1.70 & 1.71 & $y=5.52$ & 0.15 & 0.712 \\
\hline Profitability (\%) & 3.18 & 4.31 & 3.94 & 3.76 & $y=12.26$ & 0.14 & 0.711 \\
\hline Profitability $(\%)$ & 3.89 & 5.33 & 4.93 & 4.54 & $y=15.09$ & 0.10 & 0.677 \\
\hline Liquid kg Gain margin $(\$)$ & 0.49 & 0.67 & 0.60 & 0.68 & $y=1.96$ & 0.67 & 0.704 \\
\hline \multicolumn{8}{|c|}{ Female } \\
\hline Effective Operating Cost (\$) & 20.96 & 18.73 & 18.14 & 17.53 & $y=-0.1088 x+20.472$ & 0.98 & 0.001 \\
\hline Total Operating Cost $(\$)$ & 22.35 & 20.07 & 19.46 & 18.76 & $y=-0.1138 x+21.869$ & 0.89 & 0.001 \\
\hline Total Cost $(\$)$ & 51.88 & 49.02 & 47.74 & 49.27 & $y=159.81$ & 0.46 & 0.188 \\
\hline Operating Income (\$) & 15.27 & 13.39 & 17.66 & 15.44 & $y=49.87$ & 0.12 & 0.721 \\
\hline Total Revenue (\$) & 52.19 & 49.57 & 53.08 & 53.41 & $y=168.16$ & 0.28 & 0.487 \\
\hline Gross Margin (\$) & 36.90 & 36.18 & 35.34 & 37.98 & $y=118.22$ & 0.08 & 0.517 \\
\hline Net Margin (\$) & 29.84 & 29.50 & 33.61 & 34.53 & $y=102.94$ & 0.83 & 0.180 \\
\hline Economic Return (\$) & 0.30 & 0.55 & 5.34 & 4.15 & $y=0.1632 x+0.1378$ & 0.67 & 0.015 \\
\hline Break-even point (kg) & 26.60 & 25.13 & 24.47 & 25.26 & $y=25.36$ & 0.99 & 0.188 \\
\hline Leveling price (\$) & 1.94 & 1.93 & 1.75 & 1.80 & $y=-0.0059 x+1.9452$ & 0.67 & 0.018 \\
\hline Profitability (\%) & 0.11 & 0.33 & 3.12 & 2.34 & $y=0.0948 x+0.0545$ & 0.68 & 0.018 \\
\hline Profitability $(\%)$ & 0.19 & 0.49 & 3.62 & 2.73 & $y=0.1076 x+0.1427$ & 0.69 & 0.019 \\
\hline Liquid $\mathrm{kg}$ Gain margin $(\$)$ & 0.02 & 0.02 & 0.56 & 0.45 & $y=-0.0003 x^{2}+0.0271 x-0.045$ & 0.73 & 0.017 \\
\hline
\end{tabular}

P- effect significant at the 0.05 level.

Similarly, there was a positive quadratic effect for net cost margin per $\mathrm{kg}$ for female groups (Table 8), where we recorded a gain of $\$ 0.50 \mathrm{~kg}^{-1}$ with a maximum of $23.98 \%$ PAM substitution. When comparing the sexes, the male group averaged a net cost margin gain of $\$ 0.61 \mathrm{~kg}^{-1}$ and the female group averaged $\$ 0.26 \mathrm{~kg}^{-1}$. These results suggest that the best economic efficiency is achieved with the addition of PAM in the feed of lambs raised in semi-confinement.

One of the major factors in the production of lambs in a semi-confinement system is defining appropriate supplementation goals. Consequently, supplementation strategies should enable satisfactory weight gain, as well as evaluate the influence of feed costs (concentrated feed) on the profitability of the adopted production system (MACEDO, 2000; MATEUS et al., 2011; PAIM et al., 2011). In this study, we evaluated an unorthodox replacement (roughage for feed) with the aim of reducing production costs and showed a profitable production system, revealing that such substitution may be advantageous when a nutritionally balanced diet is ensured. 


\section{Conclusions}

Raising lambs in semi-confinement was economically viable and presented higher economic return when the aerial part of cassava was included in the feed.

The inclusion of the aerial parts of cassava does not affect the performance of lambs.

Replacing up to $30 \%$ of concentrated feed with the aerial parts of cassava can be recommended.

\section{References}

ARAÚJO, F. E.; SILVA FILHO, A. S.; MOUSQUER, C. J.; OLIVEIRA, DE. M. A.; MEXIA, A. A; GERON, L. J. V. Qualitative characteristics of carcasses of crossbred lambs Santa Inês $\times$ pantaneiro finished in pasture receiving supplementation Health. Journal of Hygiene and Animal RBHSA, Fortaleza, v. 8, n. 2, p. 263-278, 2014.

BRITO, O. R.; RABACOW, A. P. M.; CEREDA, M. P. Classification of nine month-old cassava cultivars by cyanide levels. Gene Conservetion, Brasilia, v. 12, n. 1, p. 35-49, 2013.

BUTOLO, J. E. Quality of ingredients in animal feed. Campinas: Brazilian Animal Nutrition College, 2002. $430 \mathrm{p}$.

CARCIOFI, A. C. Theoretical course on practical nutrition cats and dogs. Jaboticabal: An industrial FCAV Unesp, 2008. 80 p.

CARVALHO; D. M. G.; SILVA CABRAL, L.; SILVA, J. J.; ABREU, J. G.; GALATTI, R. L.; DE PAULA GENTILE, G. G.; RUFINO JUNIOR, J. Suplementos para terminação de ovinos em pastos de Brachiaria brizantha cv. Marandu. Semina: Ciências Agrárias, Londrina, v.36, n.1, p.313-326, 2015.

CARVALHO, J. L. H.; PERIM, S.; COSTA, I. R. S. Part Air cassava in animal feed. I. Nutritive value and quality of silage. Planaltina: EMBRAPA, CPAC, 1983. 6 p. (Embrapa, CPAC Technical Communication, 29).

CARVALHO, V. D.; PAULA, M. B. de; JUSTE JÚNIOR, E. S. G. Efeito da época de colheita no rendimento e composição química de fenos da parte aérea de dez cultivares de mandioca. Revista Brasileira de Mandioca, Cruz das Almas, v. 4, n. 1, p. 43-59, 1985.

DETMANN, E.; PAULINO, M. F.; VALADARES FILHO, S. C.; HUHTANEN, P. Nutritional aspects applied to grazing cattle in the tropics: a review based on Brazilian results. Semina: Agricultural Sciences, Londrina, v. 35, n. 4, p. 2829-2854, 2014.

FIALHO, J. de F.; VIEIRA, E. A. Cassava in the cerrado: technical guidelines. Mandioca no Cerrado: orientações técnicas. Planaltina, DF: Embrapa Cerrado, 2011. 208 p.

FERNANDES, A. R. M.; ORRICO JUNIOR, M. A. P.; ORRICO, A. C. A.; VARGAS JUNIOR, F. M.; OLIVEIRA, A. B. M. Performance and qualitative characteristics of carcass and meat of feedlot lambs fed diets containing soybean or protected fat. Journal of Animal Science, Viçosa, v. 40, n. 8, p. 1822-1829, 2011.

FORBES, J. M. Dietary awareness. Applied Animal Behavior Science, Atlanta, v. 57, n. 5, p. 287-297, 1998.

GOULARTE, S. R.; ÍTAVO, L. C. V.; ÍTAVO, C. C. B. F.; DIAS, A. M.; MORAIS, M. G.; SANTOS, G. T.; OLIVEIRA, L. C. S. Ingestive behavior and nutrient digestibility in cows fed different levels of concentrate. Brazilian Archives of Veterinary Medicine and Animal Science, Belo Horizonte, v. 63, n. 2, p. 414-422, 2011.

HILL, J. Impacts of technology on nutritional feeds offered to horses. Animal Feed Science and Technology, Atlanta, v. 138, n. 2, p. 92-117, 2007.

HOFFMANN, R.; ENGLER, J. J. C.; SERRANO, O.; THAME, A. C. M.; NEVES, I. N. Management agricultural company. $7^{\text {th }}$ ed. São Paulo: Pioneer, 1987. v. $1,325 \mathrm{p}$.

HOLDEN, L. A. Comparison of methods of in vitro dry matter digestibility for ten feeds. Journal of Dairy Science, Atlanta, v. 82, n. 8, p. 1791-1794, 1999.

HOLZER, Z.; AHARONI, Y., LUBIMOV, V. The feasibility of replacement of grain by tapioca in diets for growing-fattening cattle. Animal Feed Science and Technology, Atlanta, v. 64, n. 2-4, p. 133-141, 1997.

INSTITUTO BRASILEIRO DE GEOGRAFIA E ESTATÍSTICA - IBGE. System IBGE of automatic recovery. Bank of aggregated data. 2015. Available at: $<$ http://www.sidra.ibge.gov.br/bda/prevsaf/default.asp $>$. Accessed at: 11 dec. 2015.

LEVINE, M. D.; BERENSON, M. L.; STEPHAN, D. Statistical theory and applications. Rio de Janeiro: LTC, 2000. $811 \mathrm{p}$.

MACEDO, F. A. F.; SIQUEIRA, E. R. D.; MARTINS, E. N. Análise econômica da produção de carne de cordeiros sob dois sistemas de terminação: pastagem e confinamento. Ciência Rural, Santa Maria, v. 30, n. 4, p. 677-680. 2000.

MANERA, D. B.; VOLTOLINI, T. V.; YAMAMOTO, S. M.; ARAUJO, G. G. L.; SOUZA, R. A. Performance of sheep in grazing supplemented with concentrates 
containing co-products of fruit. Semina. Agricultural Sciences, Londrina, v. 35, n. 2, p. 1013-1022, 2014.

MARTIN, N. B.; SERRA, R.; OLIVEIRA, M. D. M.; ÂNGELO, J. A.; OKAWA, H. Sistema integrado de custos agropecuários - CUSTAGRI. Informações Econômicas, São Paulo, v. 28, n. 1, p. 7-28, 1998.

MATEUS, R. G.; SILVA, F. F.; ÍTAVO, L. C. V.; PIRES, A. J. V.; SIVA, R. R.; SCHIO, A. R. Suplementos para recria de bovinos Nelore na época seca: desempenho, consumo e digestibilidade dos nutrientes. Acta Scientiarum Animal Sciences, Maringá, v. 33, n. 1, p. 87-94, 2011.

MELO R. S.; MACHADO L. C.; GERALDO A.; OLIVEIRA L.A.; FERREIRA M.; DUTRAR. M.; SILVA L. M. Avaliação químico bromatológica e do conteúdo de compostos cianogênicos residual de cinco frações obtidas a partir do processamento da rama de mandicoca. In: JORNADA CIENTÍFICA; FIPA DO CEFET, 1.; 6.; Bambuí, 2008. Anais... Bambuí: CEFET, 2008. p. 1-4.

MODESTO, E. C.; SANTOS, G. T.; VILELA, D.; SILVA, D. C.; FAUSTINO, J. O.; JOBIM, C. C.; DETMANN, E.; ZAMBOM, M. A.; MARQUES, J. A. Caracterização químicobromatológica da silagem do terço superior da rama de mandioca. Acta Scientiarum Animal Science, Maringá, v. 26, n. 1, p. 137-146, 2004.

NATIONAL RESEARCH COUNCIL - NRC. Nutrient requirements of small ruminants. Washington, DC: National Academy Press, 2007. 384 p.

OLIVEIRA, M. V.; FERREIRA, I. C.; MACEDO JÚNIOR, G. de L.; ROSALINSKI-MORAES, F.; ANTUNES, M. M.; FRANÇA, A. M. S.; NAVES, J. G.; RODRIGUES, V. J. C. Beneficios do uso da monensina sódica na nutrição de cordeiros semi-confinados. Biosci. J., Uberlândia, v. 29, p. 1961-1970, 2013.

OTSUBO, A. A. Cultivo da mandioca na região centro sul do Brasil. Dourados: EMBRAPA Agropecuária Norte/Cruz das Almas: Embrapa Mandioca e Fruticultura Tropical, 2004. 116 p.

OWENS, F. N.; GOETSCH, A. L. Ruminal fermentation. In: CHURCH, D. C. The ruminant animal digestive physiology and nutrition. Englewood Cliffs: O. \& Books Inc., 1988. p. 146-171.

PAIM, T. P.; CARDOSO, M. T. M.; BORGES, B. O.; GOMES, E. F.; LOUVANDINI, H.; MCMANUS, C. Estudo econômico da produção de cordeiros cruzados confinados abatidos em diferentes pesos. Ciência Animal Brasileira, Goiania, v. 12, n. 1, p. 48-57, 2011.

PHENGVICHITH, V.; LEDIN, I. Effect of feeding different levels of wilted cassava foliage
(Manihotesculenta, Crantz) on the performance of growing goats. Small Ruminant Research, Atlanta, v. 71, n. 1-3, p. 109-116, 2007.

RAIJ, B. van; CANTARELLA, H.; QUAGGIO, J. A.; FURLANI, A. M. C. (Ed.). Recomendações de adubação e calagem para o Estado de São Paulo. 2. ed. Campinas: IAC, 1997. 285 p.

RAVINDRAN, V. Cassava leaves as animal feed: potential and limitations. Journal of the Science of Food and Agriculture, v. 61, n. 1, p. 145-150, 1993.

RAVINDRAN, V.; KORNEGAY, E. T.; RAJAGURU, A. $\mathrm{S}$. B. Influence of processing methods and storage time on the cyanide potential of cassava leaf meal. Animal Feed Science and Technology, Atlanta, v. 17, n. 4, p. 227 234, 1987.

STATISTICAL ANALYSIS SYSTEM INSTITUTE - SAS.SAS/STAT User's Guide: version 9.1. North Caroline, SAS Institute, 2004. 5136 p.

SILVA, D. J.; QUEIROZ, A. C. de. Análise de alimentos: métodos químicos e biológicos. 3. ed. Viçosa: UFV, 2006. $235 \mathrm{p}$.

SOARES, D. C. de P.; NOBRE, I. de S.; SOUZA, B. B. de; MARQUES, B. A. de A.; BATISTA, N. L. Efeito de diferentes níveis de concentrado e inclusão de gordura protegida na dieta sobre o desempenho produtivo e termorregulação de ovinos. Agropecuária Cientifica no Semiárido, Campina Grande, v. 9, n. 2, p. 14-20, 2013.

SOARES, J. G. G. Utilização e produção de forragem de maniçoba. In: ENCONTRO NORDESTINO DE MANIÇOBA, 1., 1989, Carpina. Anais... Carpina: IPA, 1989. p. 20-28.

SORIO, A. Integração lavoura pastagem favorece ovinocultura. Órgão Informativo da Associação Brasileira de Criadores de Ovinos/ARCO, Bagé, ano 5, n. 22, p. 15, jul./ago. 2011.

SOUZA, A. S. de; ROCHA JÚNIOR, V. R.; MOTA, A. D. S.; ROCHA, W. J. B.; OLIVEIRA, C. R.; AGUIAR, A. C. R. de; SANTOS, C. C. R. dos; MENDES, G. A. Potencial forrageiro e valor nutricional do feno de diferentes frações da parte aérea de quatro variedades de mandioca. Revista Brasileira de Saúde e Produção Animal, Fortaleza, v. 13, n. 3, p. 604-618, 2012.

SOUZA, R. A.; VOLTOLINI, T. V.; PEREIRA, L. G. R.; MORAES, S. A.; MANERA, D. B.; ARAÚJO, G. G. L. Desempenho produtivo de ovinos mantidos em pastagens de Tifton 85 recebendo doses crescentes de suplemento concentrado. Acta Scientiarum Animal Sciences, Maringá, v. 32, n. 3, p. 323-329, 2010. 
TILLEY, J. M. A.; TERRY, R. A. A two-stage technique for the in vitro digestion of forage crops. Journal of British Grassland Society, Oxford, v. 18, n. 2, p. 104111, 1963.

TOKARNIA, C. H.; DÖBEREINER, J.; PEIXOTO, P. V. Plantastóxicas do Brasil. Rio de Janeiro: Helianthus, 2000. $320 \mathrm{p}$.

URBANO, S. A.; ANDRADE FERREIRA, M. de; LIBERAL VÉRAS, R. M.; AZEVEDO, P. S. de; SANTOS FILHO, H. B. dos; VASCONCELOS, G. A. de; OLIVEIRA, J. P. F. de. Características de carcaça e composição tecidual de ovinos Santa Inês alimentados com manipueira. Brazilian Journal of Agricultural Sciences, Recife, v.1 0, n. 3, p. 466-472, 2015.

VAN SOEST, P. J. Nutritional ecology of the ruminant. 2. ed. Ithaca: Cornell University, 1994. 476 p.
Voluntary intake relation to chemical composition and digestibility. Journal Animal Science, Champaign, v. 24, n. 3, p. 834-844, 1965.

VAZ, R. Z.; LOBATO, J. F. P.; PASCOAL, L. L. Desenvolvimento de bezerros de corte desmamados aos 80 e 152 dias até os 15-16 meses de idade. Revista Brasileira de Zootecnia, Viçosa, v.40, n. 1, p.221-229, 2011.

WANAPAT, M.; PIMPA, O.; PETLUM, A.; BOONTAO, U. Cassava hay: a new strategic feed for ruminant during the dry section. Livestock Research and Rural Development, Cali, v. 9, n. 2, p. 1-5, 1997.

WYLIE, A. R. G.; CHESTNUTT, D. M. B.; KILPATRICK, D. J. Growth and carcass characteristics of heavy slaughter weight lambs: effects of sire breed and sex lamb and relationships to serum metabolites and IGF-1. Journal of Animal Science, Cambridge, v. 64, n. 2, p. 309-318, 1997. 